\title{
Could Fidicina mannifera (Hemiptera: Cicadoidea: Fidicinini) promote a resource pulse in two Brazilian Cerrado vegetation classes?
}

\author{
R. N. Oliveira ${ }^{a}$, S. S. Caramoria* and D. H. B. Maccagnan ${ }^{b}$ \\ áLaboratório de Biotecnologia, Universidade Estadual de Goiás - UEG, Câmpus Anápolis de Ciências Exatas \\ e Tecnológicas, Rodovia BR 153, 3105, Fazenda Barreiro do Meio, CEP 75132-903, Anápolis, GO, Brazil \\ 'Laboratório de Entomologia, Universidade Estadual de Goiás - UEG, Câmpus Iporá, Avenida R-2, Q. 1, \\ Novo Horizonte 2, CEP 76200-000, Iporá, GO, Brazil \\ *e-mail: samantha.salomao@ueg.br
}

Received: September 2, 2015 - Accepted: June 3, 2016 - Distributed: November 31, 2017

(With 3 figures)

\begin{abstract}
Cicadas are usually studied regarding their importance in agriculture. However, the possibility of this group to represent a pulse of nutrients can also imply on the success of a given species in the biome. The aim of this study was to assess the level of total soluble proteins and lipids of Fidicina mannifera (Fabricius, 1803), and to determine whether the species can promote a pulse of nutrients in two vegetation classes of the Brazilian Cerrado. To assess the pulse of nutrients, it was concluded the determination of total soluble proteins and lipids from samples of males and adult females of F. mannifera, and the spatial distribution of exuviae of this species was also calculated in two vegetation classes of the Brazilian Cerrado. The amount of protein provided by each individual did not differ between males and females $(\mathrm{p}=0.66)$ but females had $40 \%$ more lipids than males $(\mathrm{p}=0.05)$. Regarding $F$. mannifera the gallery forest offered $11.75 \mathrm{~g} / \mathrm{ha}$ of protein, $3.91 \mathrm{~g} / \mathrm{ha}$ of lipids, and the Cerrado stricto sensu offered $4.25 \mathrm{~g} / \mathrm{ha}$ of protein, and $1.41 \mathrm{~g} / \mathrm{ha}$ of lipid. The male cicadas have a hollow abdomen, which houses a resonance chamber for sound production in order to attract females to mate, and females store larger amounts of lipids, mainly located in the abdominal cavity, where the body fat is directly linked to the reproductive system for the development of the ovaries and egg production after emergence. The mass occurrence of $F$. mannifera in the Brazilian Cerrado and the fast availability of proteins and lipids make this species a food resource that can directly impact the diet of secondary consumers and scavengers, although the amount of nutrients available by F. mannifera does not promote a pulse of nutrients in the study site.
\end{abstract}

Keywords: Cicadidae, cicada, protein, lipids, sexual maturation.

\section{Fidicina mannifera (Hemiptera: Cicadoidea: Fidicinini) promove pulsos de nutrientes em duas fitofisionomias do Cerrado?}

\section{Resumo}

O interesse no estudo de cigarras geralmente é despertado pela sua importância na agricultura. Entretanto, a possibilidade de que este grupo represente um pulso de nutrientes pode também implicar no sucesso de sobrevivência de espécies importantes num determinado bioma. O objetivo deste trabalho foi verificar o nível de proteínas solúveis e lipídios totais de Fidicina mannifera (Fabricius, 1803) e determinar se a espécie pode promover um pulso de nutrientes em duas fitofisionomias do Cerrado. Para avaliar o pulso de nutrientes, foram determinados os níveis de proteínas solúveis e lipídios totais de machos e fêmeas adultos de F. mannifera, e também a distribuição espacial de exúvias desta espécie, em duas fitofisionomias de Cerrado. A quantidade de proteínas disponibilizada por indivíduo não diferiu entre machos e fêmeas $(\mathrm{p}=0,66)$, porém fêmeas apresentaram $40 \%$ mais lipídios do que machos $(\mathrm{p}=0,05)$. Para mata de galeria F. mannifera ofertou $11,75 \mathrm{~g} / \mathrm{ha}$ de proteína, $3,91 \mathrm{~g} / \mathrm{ha}$ de lipídios, e no cerrado stricto sensu, $4,25 \mathrm{~g} / \mathrm{ha}$ de proteína, e 1,41 g/ha de lipídio. Machos de cigarras possuem um abdômen oco, que abriga uma câmara de ressonância para a produção de som com o objetivo atração de fêmeas para acasalar, por outro lado as fêmeas armazenam maiores quantidades de lipídios, localizados principalmente na cavidade abdominal, onde a gordura corporal está diretamente ligada ao aparelho reprodutor para o desenvolvimento dos ovários, e produção de ovos após a emergência. A ocorrência em massa de F. mannifera no Cerrado, bem como a disponibilidade de proteínas e lipídios de fácil acesso, faz desta espécie um recurso alimentar que pode impactar diretamente na dieta de consumidores e detritívoros secundários, embora quantidade de nutrientes disponibilizados por $F$. mannifera não promova um pulso de nutrientes no local estudado.

Palavras-chave: Cicadidae, cigarra, proteínas totais, lipídios solúveis, maturação sexual. 


\section{Introduction}

In biological communities the environmental processes, such as the flow of nutrients in the ecosystem, are diverse and critical to maintain the ecological balance. According to Begon et al. (2005), the integration of different trophic levels forms the basis that promotes and provides resources and energy for living organisms. The ecosystem services and processes, such as material flow, nutrient cycling and soil formation, can be translated in terms of indirect economic benefits that are not destroyed while in use, but are crucial to the economy in the long term (Primack and Rodrigues, 2001).

According to Yang et al. (2008), the resource pulses are defined as infrequent phenomena, characterized by their large magnitude, short time for occurrence and the addition of nutrients to the ecosystem. Efforts related to resource pulses have increased in the last decade (Peek and Forseth, 2003; Yang, 2005; Nowlin et al., 2008; Yang et al., 2008), which contributed to a better understanding of natural environments for two reasons: first, because the natural systems are influenced by some component of the pulse, and second, because these pulses provide opportunities to investigate many ecological interactions (Ostfeld and Keesing, 2000; Small et al., 2013; Yang, 2013).

Arthropods are the most abundant herbivores and detritivores (Seasted and Crossley, 1984) and influence the productivity of plants, the cycling and the nutrient flow in terrestrial ecosystems (Crossley, 1977; Mellec et al., 2011). The cicadas (Hemiptera: Cicadoidea) are insects usually bodily medium to large-sized insects and are very common in the tropics and subtropics. In the last decade the number of species recorded in Brazil for this group was 160, and efforts have been made, pointing to an increasing trend for the occurrences in the country (Gogala et al., 2015; Maccagnan and Sanborn, 2015). The adult life stage of cicadas, which lasts a few weeks, is considered ephemeral compared to their nymphal stage (Boulard, 1965). Since the hatch of eggs, nymphs go underground in search of the xylem of the roots to feed themselves. The emergence of cicadas is the phenomenon in which the nymphs leave the subsoil to the surface and come to accomplish metamorphosis and later reproduction (Young, 1975; Yang et al., 2008).

Species of cicadas have been associated to resource pulses by their emergence at high density in a short period of time (Aoki et al., 2011). This phenomenon occurs especially in females, because they have the complete abdomen, making them more attractive for predators, unlike the males (Brown and Chippendale, 1973). As cicadas have large amounts of dissolved nitrogen $(\mathrm{N})$, phosphorus (P) and carbon (C), they emerge to become a significant trophic action (Mellec et al., 2011). Such animals promote the translocation of nutrients from the subsoil, where the nymphs fed on the plant stems, and adults are susceptible to predation (Young, 1980). Thus, they provide a lot of nutrients for the plants when they stir the subsurface layer, and are an additional source of food for insectivorous organisms (Seasted and Crossley, 1984).
For some environments, species of cicadas have play a key role by the large number of individuals that emerge and synchronously by the large dimension that they generally present (Callaham Junior et al., 2000; Yang, 2004).

There are few scientific efforts involving terrestrial insects and the promotion of resource pulses, but it is important to show how much predators can feed in their daily nutritional needs. Among the species of cicadas that occur in Brazil, Fidicina mannifera (Fabricius, 1803) is considered to be of large size, as well as Quesada gigas (Olivier, 1790), to which it has been attributed nutrient pulse promotion in urban environment, where it is known that Q. gigas has a massive emergency (Sazima, 2009; Aoki et al., 2011). This study aims to investigate, for an abundant species in natural environments such as F. mannifera, whether it is possible to observe the occurrence of the same phenomenon. For this purpose, this study assessed the level of nutrients, such as total soluble proteins and lipids from Fidicina mannifera (Hemiptera: Cicadidae), in comparison between males and females, and the biometric parameters of both specimens, in order to determine whether the species can promote a pulse of nutrients (resources) in an area of the Brazilian Cerrado biome.

\section{Material and Methods}

The field work was conducted in The Agroecological Technology Center for Small Farmers (AGROTEC), an agroextractivist area in the municipality of Diorama, Goiás, Brazil ( $\left.16^{\circ} 14^{\prime} \mathrm{S}, 51^{\circ} 16^{\prime} \mathrm{W}\right)$. The AGROTEC has 125 hectares composed of vegetation classes of shrub Cerrado, Cerrado woodland, gallery forest, patches and portions of barns. To carry out the collections, it were used a Cerrado stricto sensu area and a gallery forest, with samples taken at the period of emergence of the species, from August to December 2013, as field surveys previously conducted that pointed, regarding the emerging period of F. mannifera (Oliveira, 2015). As the species F. mannifera showed the greatest abundance in the collected area, this group was used for the analyses in this study.

The adults of $F$. mannifera were collected during their period of emergence, using entomological net, where the specimens captured were sexed and separated by the month in which the collection was made. This collection method was chosen so the biochemical components to be determined could be preserved until performing the assays. All samples were collected from 8:00am to 6:00pm, during two consecutive days, with intervals of one week between each collection. Determination of the number of emerged individuals per area was performed through exuviae collection of the last instar nymph of F. mannifera. These molts usually fix the medium height at the stems of their host trees. For each vegetation class, three sample areas were chosen with $20 \times 20 \mathrm{~m}$ (total area $1200 \mathrm{~m}^{2}$ ), subdivided into squares of $5 \times 5 \mathrm{~m}$, where the exuviae occurrence was examined. Similar to Callaham Junior et al. (2000), the squares of $25 \mathrm{~m}^{2}$ were assessed by 
inspection of the plant stems and surrounding the base of the trees, twice a month, from August to December of 2013.

In the Laboratório de Entomologia, exuviae were sexed and identified following the identification keys provided by Maccagnan and Martinelli (2011) and Motta (2003),being then quantified. The distribution pattern of cicadas was based on the collected molt samples, and calculated by the following dispersion indexes: Morisita Index (MI), in which values equal to 1 determined a random distribution, values higher than 1 determined aggregate distributions and less than 1 showed uniform distributions. The exponent $\mathrm{k}$ was used for the Negative Binomial Distribution (kNBD), where negative values indicate uniform distribution, low and positive values $(\mathrm{k}<2)$ indicate highly aggregated distribution, values between 2 and 8 indicate a moderate aggregation and values above 8 suggest the occurrence of random distribution (Elliott, 1979).

The precipitation data for the collection period in the studied area were obtained by TOVAS (TRMM Online Visualization and Analysis System), online data system developed and maintained by NASA GES DISC. The system acquired data from the monthly accumulated rainfall, based on geographic coordinates where the study was conducted, with daily measurements for any selected period, which in this study was from September to December 2013.

All samples had the water content determined in order to use the dry mass for biochemical tests. One gram of dry mass was considered as the amount of material to be obtained after incubation of specimens for one week, with daily mass measurements until the constant weight, in a circulating air oven at $40{ }^{\circ} \mathrm{C}$ (adapted from IAL, 2005). The protein content was performed by the method of Bradford (1976), briefly: for each sample of dried material $(0.3 \mathrm{~g}), 10 \mathrm{~mL}$ of sodium phosphate buffer $\left(0.1 \mathrm{~mol} \mathrm{~L}^{-1}\right.$, $\mathrm{pH}$ 7.0) were added, the mixture was homogenized for $60 \mathrm{~min}$ at $4{ }^{\circ} \mathrm{C}$ and centrifuged at 2,000 rpm for $10 \mathrm{~min}$. The precipitate was discarded and the total volume of supernatant was measured and used for the test as follows: $0.1 \mathrm{~mL}$ aliquots of supernatant were mixed with $5 \mathrm{~mL}$ of Bradford reagent and, after $10 \mathrm{~min}$ at room temperature, measurements were taken at $595 \mathrm{~nm}$. The amount of total protein was calculated using a standard curve with bovine serum albumin (Sigma-Aldrich, USA) at concentrations from 5 to $50 \mu \mathrm{g} / 100 \mu \mathrm{L}$. The protein content in samples was expressed as $\mathrm{mg} / \mathrm{g}$ dry mass.

The lipid content was determined by the Soxhlet method (Pregnolatto and Pregnolatto, 1985), with some modifications: $0.5 \mathrm{~g}$ of dry mass was added into a cartridge coupled together with a flat bottom flask containing $100 \mathrm{~mL}$ of petroleum ether (Sigma-Aldrich, USA) for extraction. The solution was under heating at $105^{\circ} \mathrm{C}$ for $60 \mathrm{~min}$ and was then placed for evaporation of the solvent. The resulting lipid material extracted was weighed and calculated and expressed as mean and standard deviation. The content of lipids in the samples was expressed in $\mathrm{mg} / \mathrm{g}$ dry mass. These data added to the spatial distribution of the species were used to express the content of proteins and lipids for each phytophysiognomy.

Statistical analyses were performed in order to determine if there was any significant difference comparing the weight of fresh and dry individuals, total proteins and lipids between males and females, using a t-test. For data with non-normal distribution, the non-parametric test of Wilcox was adopted to verify the differences. The availability of nutrients offered by cicadas month to month was analyzed by ANOVA and Tukey test a posteriori. All tests were done through the program R (R Core Development Team, 2012), considering $\mathrm{p}<0.05$.

\section{Results}

During the study period, 58 adult specimens of F. mannifera were collected, showing $63.8 \%$ of males and $36.2 \%$ of females (September: 9 males $/ 2$ females; October: 19 males/3 females; November: 9 males/ 6 females; December: 3 males/ 7 females). Both sexes differed on mass and nutritional aspects. The total water content in adult females was significantly higher than in males $(t=-2.4196$, $\mathrm{p}=0.05)$, however, the dry mass did not differ between sexes $(\mathrm{t}=-2.3675, \mathrm{p}=0.08)$ (Table 1$)$.

The amount of protein provided by each individual did not differ between males and females $(\mathrm{t}=-0.4546$, $\mathrm{p}=0.66$ ), but the $F$. mannifera females showed $40 \%$ more mass than males in lipids $(\mathrm{w}=1, \mathrm{p}=0.05)$. The available proteins and lipids offered by males and females increased in samples collected on November and December 2013 (Figures 1 and 2).

Along the period of emergence (September to November 2013), the content of proteins for males increased ( $p<0.001$ ), but in the months of November and December 2013 the samples showed stabilization, and did not presented any alteration $(p=0.38)$. In females, although the same difference along the sampling months $(p<0.001)$ could be observed, there were more proteins found in the samples obtained in November 2013.

Table 1. Water content and dry weight of males and females of $F$. mannifera considering the emerging period in The Agro-ecological Technology Center (AGROTEC).

\begin{tabular}{cccccc}
\hline & \multicolumn{2}{c}{ Water (\%) } & & \multicolumn{2}{c}{ Dry weight (g) } \\
\cline { 2 - 3 } \cline { 5 - 6 } & Male & Female & & Male & Female \\
\hline Sept/13 & $26.38 \pm 0.17$ & $27.54 \pm 0.32$ & & $0.85 \pm 0.075$ & $1.10 \pm 0.14$ \\
Oct/13 & $25.84 \pm 0.30$ & $22.69 \pm 0.21$ & & $0.81 \pm 0.10$ & $0.88 \pm 0.04$ \\
Nov/13 & $22.81 \pm 0.25$ & $26.13 \pm 0.63$ & & $0.79 \pm 0.092$ & $0.99 \pm 0.21$ \\
Dec/13 & $24.95 \pm 0.20$ & $23.63 \pm 0.35$ & & $0.79 \pm 0.07$ & $0.84 \pm 0.16$ \\
\hline
\end{tabular}




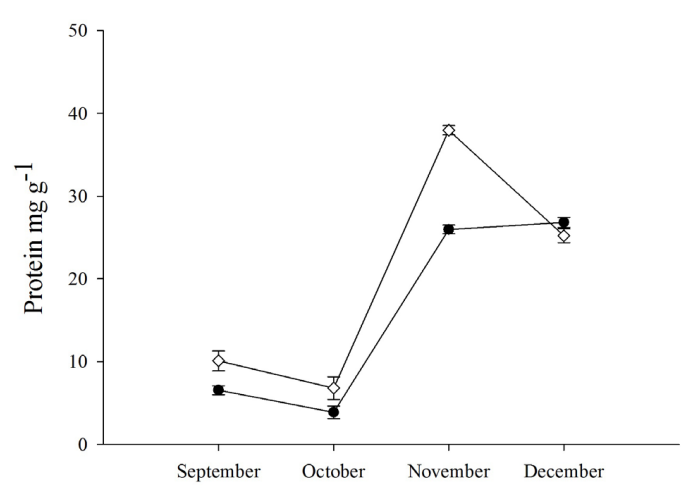

Figure 1. Proteins $\left(\mathrm{mg} \mathrm{g}^{-1}\right)$ in adult males and females of F. mannifera along the emerging period, collected on the Agroecological Technology Center for Small Farmers (AGROTEC), Diorama, Goiás. Open diamonds show the amount of protein present in females.

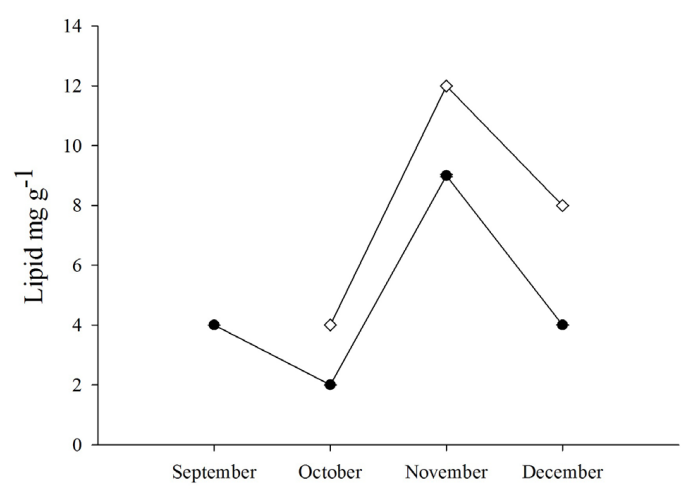

Figure 2. Profile of lipids $\left(\mathrm{mg} \mathrm{g}^{-1}\right)$ in adult males and females of $F$. mannifera along emerging period, collected on the Agroecological Technology Center for Small Farmers (AGROTEC), Diorama, Goiás. Open diamonds demonstrate the amount of lipids present in females.

For lipids, there was no difference in the quantity supplied by males in the sampled months $(p=0.44)$, but for females (excluding the month of September, when it was not possible to perform the assay in triplicate) differences between November/December $(\mathrm{p}=0.03)$, November/October $(\mathrm{p}=0.002)$, and for December/October were observed $(p=0.06)$. As estimated, for gallery forest, $F$. mannifera could offer $11.75 \mathrm{~g} /$ ha of protein and $3.91 \mathrm{~g} /$ ha of lipid; for the cerrado woodland, it could offer $4.25 \mathrm{~g} /$ ha of protein and $1.41 \mathrm{~g} /$ ha of lipid. The collected exuviae presented 53 individuals from the gallery forest and 15 from the cerrado stricto sensu. The spatial distribution of $F$. mannifera was highly aggregated in both vegetation classes showing $7.66(\mathrm{MI})$ and 0.15 (kNBD) in the gallery forest, 7.77 (MI) and $0.06(\mathrm{kNBD})$ in the cerrado woodland.

September 2013 was dry in Cerrado, showing only $75 \mathrm{~mm}$ of rainfall, and the onset of the rains in that region starts in October, with a jump to $253 \mathrm{~mm}$ accumulated in the month. The periods of greatest rainfall on the studied

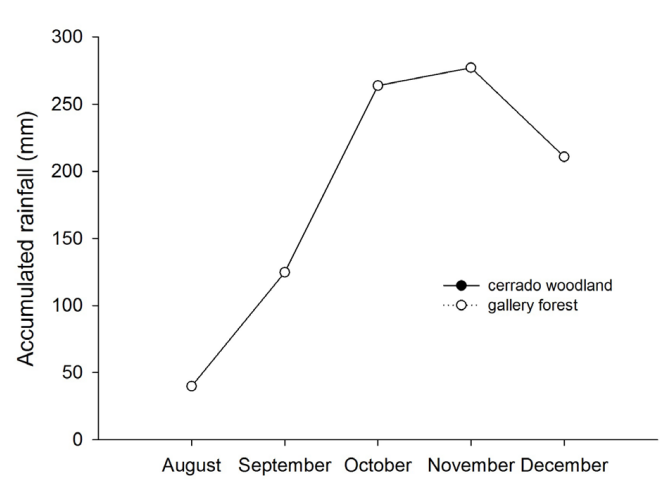

Figure 3. Precipitation $(\mathrm{mm})$ for the months sampled in 2013 in the areas of cerrado woodland (closed symbol) and gallery forest (open symbol) in the Agroecological Technology Center for Small Farmers (AGROTEC), Diorama, GO, Brazil.

site were in November and December, with $436 \mathrm{~mm}$ to $490 \mathrm{~mm}$ (Figure 3).

\section{Discussion}

The biochemical content of $F$. mannifera showed that females are more nutritional than males, especially because they are richer in fat items. Stamps and Gon (1983) suggested that females are more suitable as an energy source than males, which can facilitate their predation. The availability of lipids offered by $F$. mannifera females shows that the anatomical difference between the sexes in cicadas interferes with the amount of energy available to the environment. In the case of cicadas, males have a hollow abdomen, which houses a resonance chamber for the production of sound in order to attract females for mating (Cooley, 2001; Sueur, 2003; Boulard, 2006), while females accumulate nutrient reserves to be used for breeding.

The cicada females, along the maturation period, store larger amounts of lipids, mainly localized in the abdominal cavity, where the body fat is directly related to the reproductive system for the development of the ovaries and egg production after emerging (Brown and Chippendale, 1973). The influence of nutrients on sexual maturation and reproduction was demonstrated by Blay and Yuval (1997), where the authors related the influence of the amount of nutrients on the reproductive performance in Diptera. In the case of cicadas, during their nymphal stage, the reserve of nutrients is used to differentiate reproductive systems (Brown and Chippendale, 1973), wherein the amount of lipids will ensure the ability of the females to reproduce and lay eggs.

During the dry season in the Cerrado biome, the atmospheric evaporative demand and the incidence of solar radiation substantially increase (Miranda et al., 1997; Meinzer et al., 1999). Some plant species have access to water reserves located in the ground due to the depth that the roots reach, but there is no sufficient water extraction, 
guaranteed to overcome the atmospheric evaporative demand (Franco, 1998, 2008). Consequently, certain species reduce the sap flow in response to environmental conditions (Naves-Barbiero et al., 2000; Franco, 2002; Bucci et al., 2004; Palhares et al., 2010), thus the amount of nutrients flowing through the plant may decrease.

Cicadas have as a food source the xylem sap (White and Strehl, 1978) and the smaller amount of proteins and lipids during the wet-to-dry season transition must be linked to reduced sap flow in their host, leading to low nutrient assimilation. Carvalho et al. (2007) have also shown that leaves collected during the rainy season had higher rates of $\mathrm{N}$ and $\mathrm{P}$ compared to those collected in the dry season. Another factor that might have indirect influence on F. mannifera is the sprout of leaves during the dry-rain transition because young leaves tend to have higher nutrient leaching as a result of the rains. Thus, their production before the rainy season reduces the loss of nutrients (Sarmiento et al., 1985; Mariano et al., 2009) and increases the photosynthetic efficiency (Felfili et al., 1999) which can directly increase the xylem sap flow, which is assimilated by $F$. mannifera.

Aggregated emergency of $F$. mannifera also occurs with other cicadas, as in Q. gigas (Pereira, 2013) and Fidicinoides sp. (Ribeiro et al., 2006). The aggregated spatial pattern associated to the amounts of proteins and lipids translocated by $F$. mannifera from the subsoil to the surface, makes this species an abundant resource of energy for its predators.

The flow of nutrients in cicadas has been discussed by several authors, either involving nitrogen (Callaham Junior et al., 2000; Yang, 2004, 2013; Aoki et al., 2011), in association with heavy metals (Robinson Junior et al., 2007), and proteins and lipids (Aoki et al., 2011). Notwithstanding, in the Cerrado sample, F. mannifera could not promote a pulse of nutrients, since the local density of the populations and the amount of nutrients released per hectare was considered small in comparison to the literature. An example of an annual cicada species in Brazil is Q. gigas, which, studied in urban environments away from natural predators, provided $545 \mathrm{~g}$ of protein and $363 \mathrm{~g}$ of lipids per hectare (Aoki et al., 2011). Callaham Junior et al. (2000) indicate that a community composed of five species of cicadas can provide about of $4 \mathrm{~kg}$ of nitrogen per hectare in one year in the tallgrass prairie in North America. The high difference in the amount of nutrients available between the results of the works cited above and the presented here is mainly due to the difference in the abundance of cicadas between the areas. The areas of study evaluated in this work are characterized by being natural and with large vegetable diversity, thus reducing the probability of a particular species being super abundant. On the other hand, the data presented in Aoki et al. (2011) are from urban areas, where the environment is simplified and favors the abundance of species that adapt to it. The environment studied by Callaham Junior et al. (2000) is a grassland that naturally presents itself as a more uniform environment (Begon et al., 2005), which also favors the abundance of certain species.

Due the fact that $F$. mannifera shows preference to the gallery forest areas (Oliveira, 2015), its predators in this phytophysiognomy consume larger amounts of nutrients when compared to the cerrado woodland. Consumption of F. mannifera brings energy benefits and food utilization by predators. Cicadas are food source for animals that do not feed on plant structures, such as spiders and insectivorous birds (Aoki et al., 2011), and insect-derived protein has better quality compared to that derived from seeds and fruits (Robbins et al., 2005). The lipid consumption by birds directly influences the size of the nest (Ankney and Afton, 1988). Moreover, the register of birds feeding on cicadas, by Sazima (2009) and by Aoki et al. (2011), show that the cicadas, by apparently not having anti-predation behavior, become a food source, primarily for birds, but also for other opportunistic predators.

\section{Conclusions}

The mass occurrence of F. mannifera in the Brazilian Cerrado, associated with its spatial aggregation, and the availability of proteins and lipids make this species a food resource that can directly impact the diet of secondary consumers and scavengers, although this species does not promote a pulse of resources in the studied area. It is necessary that more animal and plant species can be studied in this biome in order to know what possible impact $F$. mannifera may have on the food chain.

\section{Acknowledgements}

The authors thank to $\mathrm{CNPq}$ for the project support (486577/2013-9). Rogério Nunes Oliveira thanks to Universidade Estadual de Goiás for the graduate scholarship. Samantha Caramori was supported by the University Research and Scientific Production Support Program (PROBIP/UEG).

\section{References}

ANKNEY, C.D. and AFTON, A.D., 1988. Bioenergetics of breeding northern shovelers: diet, nutrient reserves, clutch size, anda incubation. The Condor, vol. 90, no. 2, pp. 459-472. http:// dx.doi.org/10.2307/1368574.

AOKI, C., LOPES, F.S., OLIVEIRA, A.M.R., SOUZA, F.L. and MARQUES, M.R., 2011. Nutrient flux associated with the emergence of Quesada gigas Oliver (Hemiptera:Cicadidae) in an urban ecosystem. Neotropical Entomology, vol. 40, no. 4, pp. 36-439. PMid:21952958. http://dx.doi.org/10.1590/S1519$566 \times 2011000400004$

BEGON, M., TOWNSEND, C.R. and HARPER, J.L., 2005. Ecology: from individuals to ecosystems. Oxford: Blackwell Publishing. 737 p.

BLAY, S. and YUVAL, B., 1997. Nutritional correlates of reproductive success of male Mediterranean fruit flies (Diptera: Tephritidae). Animal Behaviour, vol. 54, no. 1, pp. 59-66. PMid:9268435. http://dx.doi.org/10.1006/anbe.1996.0445. 
BOULARD, M., 1965. Notes sur la biologie larvaire de las cigales (Hom. Cicadidae). Annales de la Société Entomologique de France, vol. 1, no. 3, pp. 503-521.

BOULARD, M., 2006. Acoustic signals, diversity and behaviour of cicadas (Cicadidae, Hemiptera). In: S. DROSOPOULOS and M. CLARIDGE. Insect sounds and communication: physiology, behaviour, ecology and evolution. Boca Raton: CRC Press, pp. 331-349.

BRADFORD, M., 1976. A rapid and sensitive method for the quantitation of microgram quantities of protein utilizing the principle of protein-dye binding. Analytical Biochemistry, vol. 72, no. 1-2, pp. 248-254. PMid:942051. http://dx.doi.org/10.1016/00032697(76)90527-3

BROWN, J.J. and CHIPPENDALE, G.M., 1973. Nature and fate of the nutrient reserves of the periodical (17 year) Cicada. Journal of Insect Physiology, vol. 19, no. 6521, pp. 607-614. http://dx.doi.org/10.1016/0022-1910(73)90069-3.

BUCCI, S.J., GOLDSTEIN, G., MEINZER, F.C., FRANCO, A.C., CAMPANELLO, P. and SCHOLZ, F.G., 2004. Mechanisms contributing to seasonal homeostasis of minimum leaf water potential and predawn disequilibrium between soil and plant water potential in Neotropical savanna trees. Trees (Berlin), vol. 19, no. 3, pp. 296-304. http://dx.doi.org/10.1007/s00468-004-0391-2.

CALLAHAM JUNIOR, M.A., WHILES, M.R., MEYER, C.K., BROCK, B.L. and CHARTLON, R.E., 2000. Feeding ecology and emergence production of annual cicadas (Homoptera: Cicadidae) in tallgrass prairie. Oecologia, vol. 123, no. 4, pp. 535-542. http:// dx.doi.org/10.1007/s004420000335.

CARVALHO, A.N.P., BUSTAMANTE, M.M.C., KOZOVITS, A.R. and ASNER, G.P., 2007. Variações sazonais nas concentrações de pigmentos e nutrientes em folhas de espécies de cerrado com diferentes estratégias fenológicas. Revista Brasileira de Botanica, vol. 30, no. 1, pp. 19-27. http://dx.doi.org/10.1590/ S0100-84042007000100003.

COOLEY, J.R., 2001. Long-range acoustical signals, phonotaxis, and risk in the sexual pair-forming behaviors of Okanagana canadensis and O. rimosa (Hemiptera: Cicadidae). Annals of the Entomological Society of America, vol. 94, no. 5, pp. 755-760. http://dx.doi.org/10.1016/j.jaridenv.2006.02.014.

CROSSLEY, D.A., 1977. The role of terrestrial saprophagous arthropods in forest soils: current status of concepts. In: W.J. MATTSON, ed. The role of arthropods in forest ecosystems. New York: Springer-Verlag, pp. 49-56.

ELLIOTT, J.M., 1979. Some methods for the statistical analysis of sample benthic invertebrates. 2. ed. Ambleside: Freshwater Biological Association, pp. 157. http://dx.doi.org/10.1002/ iroh.19740590250.

FELFILI, J.M., SILVA JÚNIOR, M.C., DIAS, B.J. and REZENDE, A.V., 1999. Estudo fenológico de Stryphnodendron adstringens (Mart.) Coville no cerrado sensu stricto da Fazenda Água Limpa no Distrito Federal, Brasil. Revista Brasileira de Botanica, vol. 22, no. 1, pp. 1-10. http://dx.doi.org/10.1590/S0100-84041999000100011.

FRANCO, A.C., 1998. Seasonal patterns of gas exchange, water relations and growth of Roupala montana, an evergreen savanna species. Plant Ecology, vol. 136, no. 1, pp. 69-76. http://dx.doi. org/10.1023/A:1009763328808.

FRANCO, A.C., 2002. The cerrados of Brazil. New York: Columbia University Press. 368 p.
FRANCO, A.C., 2008. Relações hídricas em plantas do cerrado: as plantas lenhosas do cerrado transpiram livremente. In: C.H.B.A. PRADO and C.A. CASALI. Fisiologia Vegetal: práticas em relações hidricas, fotossintese e nutrição animal. Barueri: Malone, pp. 1-6.

GOGALA, M., ŠPORAR, K., SANBORN, A.F. and MACCAGNAN, D.H.B., 2015. New cicada species of the genus Guyalna (Hemiptera: Cicadidae) from Brazil. Acta Entomologica Slovenica, vol. 23, no. 2, pp. 105-116.

INSTITUTO ADOLFO LUTZ - IAL, 2005. Normas Analiticas do Instituto Adolfo Lutz. Métodos químicos e fisicos para análise de alimentos. 4. ed. São Paulo: IMESP, pp. 98-99.

MACCAGNAN, D.H.B. and MARTINELLI, N.M., 2011. Description and key to the fifth-instars of some Cicadas (Hemiptera: Cicadidae) associated with coffee plants in Brazil. Neotropical Entomology, vol. 40, no. 4, pp. 445-451. PMid:21952960. http:// dx.doi.org/10.1590/S1519-566X2011000400006.

MACCAGNAN, D.H.B. and SANBORN, A.F., 2015. Orialella aerizulae (Hemiptera: Cicadidae): first record in Brazil. The Florida Entomologist, vol. 98, no. 3, pp. 984-986. http://dx.doi. org/10.1653/024.098.0331.

MARIANO, K.R., BARRETO, L.S., SILVA, A.H.B., NEIVA, G.K.P. and AMORIN, S., 2009. Fotossíntese e tolerância protoplasmática foliar em Myracrodruon urundeuva Fr. All. submetida ao déficit hídrico. Revista Caatinga, vol. 22, no. 1, pp. 72-77.

MEINZER, F.C., GOLDSTEIN, G., FRANCO, A.C., BUSTAMANTE, M., IGLER, E., JACKSON, P., CALDAS, L. and RUNDEL, P.W., 1999. Atmospheric and hydraulic limitations on transpiration in Brazilian cerrado woody species. Functional Ecology, vol. 13, no. 2, pp. 273-282. http://dx.doi.org/10.1046/j.1365-2435.1999.00313.x.

MELLEC, A., GEROLD, G. and MICHALZIK, B., 2011. Insect herbivory, organic matter deposition and effects on belowground organic matter fluxes in a central European oak forest. Plant and Soil, vol. 342, no. 1-2, pp. 393-403. http://dx.doi.org/10.1007/ s11104-010-0704-8.

MIRANDA, A.C., MIRANDA, H.S., LLOYD, J., GRACE, J., FRANCEY, R.J., MCINTYRE, J.A., MEIER, P., RIGGAN, P., LOCKWOOD, R. and BRASS, J., 1997. Fluxes of carbon, water and energy over Brazilian cerrado: an analysis using eddy covariance and stable isotopes. Plant, Cell \& Environment, vol. 20, no. 3, pp. 315-328. http://dx.doi.org/10.1046/j.1365-3040.1997.d01-80.x.

MOTTA, P.C., 2003. Cicadas (Hemiptera, Auchenorrhyncha, Cicadidae) from Brasília (Brazil): exuviae of the last instar with key of the species. Revista Brasileira de Zoologia, vol. 20, no. 1, pp. 19-22. http://dx.doi.org/10.1590/S0101-81752003000100005.

NAVES-BARBIERO, C.C., FRANCO, A.C., BUCCI, S.J. and GOLDSTEIN, G., 2000. Fluxo de seiva e condutância estomática de duas espécies lenhosas sempre-verdes no campo sujo e cerradão. Revista Brasileira de Fisiologia Vegetal, vol. 12, no. 2, pp. 119134. http://dx.doi.org/10.1590/S0103-31312000000200003.

NOWLIN, W.H., VANNI, M.J. and YANG, L.H., 2008. Comparing resource pulses in aquatic and terrestrial ecosystems. Ecology, vol. 89, no. 3, pp. 647-659. PMid:18459329. http://dx.doi. org/10.1890/07-0303.1.

OLIVEIRA, R.N., 2015. Cigarras (Hemiptera: Cicadidae) no Cerrado: Análise de fauna e pulso de nutrientes. Anápolis: Universidade Estadual de Goiás, 45 p. Dissertação de Mestrado em Recursos Naturais do Cerrado. 
OSTFELD, R.S. and KEESING, F., 2000. Pulsed resources and community dynamics of consumers in terrestrial ecosystems. Trends in Ecology \& Evolution, vol. 15, no. 6, pp. 232-237. PMid:10802548. http://dx.doi.org/10.1016/S0169-5347(00)01862-0.

PALHARES, D., FRANCO, A.C. and ZAIDAN, L.B.P., 2010. Respostas fotossintéticas de plantas de cerrado nas estações seca e chuvosa. Revista Brasileira de Biociências, vol. 8, no. 2, pp. 213-220.

PEEK, M.S.. and FORSETH, I.N., 2003. Microhabitat responses to resource pulses dependent in the aridland perennial, Cryptantha flava. Journal of Ecology, vol. 91, pp. 457-466. http://dx.doi. org/10.1046/j.1365-2745.2003.00778.x.

PEREIRA, N.A., 2013. Distribuição espacial de Quesada gigas (Olivier, 1790) (Hemiptera: Cicadidae) na cultura do café. Jaboticabal: Universidade Estadual Paulista "Júlio de Mesquita Filho", 44 p. Dissertação de mestrado em Agronomia (Entomologia Agrícola).

PREGNOLATTO, W. and PREGNOLATTO, N.P., 1985. Métodos químicos e físicos para análises de alimentos. In: W. PREGNOLATTO and N.P. PREGNOLATTO, coord. Normas analíticas do Instituto Adolfo Lutz. 3. ed. São Paulo: Instituto Adolfo Lutz. 533 p.

PRIMACK, R. and RODRIGUES, E., 2001. Biologia da conservação. Londrina: Efraim Rodrigues. 328 p.

R CORE DEVELOPMENT TEAM, 2012. $R$ : a language and environment for statistical computing. Vienna: R Foundation for Statistical Computing.

RIBEIRO, R., PEREIRA, M.F.A., MARTINELLI, N.M. and MACCAGNAN, D.H.B., 2006. Dispersão de Fidicinoides sp. (Hemiptera : Cicadidae) em cafeeiro. Cientifica, vol. 34, no. 2, pp. 263-268. http://dx.doi.org/10.15361/1984-5529.2006v34n2p263+-+268.

ROBBINS, C.T., FELICETTI, L.A. and SPONHEIMER, M., 2005. The effect of dietary protein quality on nitrogen isotope discrimination in mammals and birds. Oecologia, vol. 144, no. 4, pp. 534-540. http://dx.doi.org/10.1007/s00442-005-0021-8.

ROBINSON JUNIOR, G.R., SIBRELL, P.L., BOUGHTON, C.J. and YANG, L.H., 2007. Influence of soil chemistry on metal and bioessential element concentrations in nymphal and adult periodical cicadas (Magicicada spp.). The Science of the Total Environment, vol. 374, no. 2-3, pp. 367-378. PMid:17258290. http://dx.doi.org/10.1016/j.scitotenv.2006.12.031.

SARMIENTO, G., GOLDSTEIN, G. and MEINZER, F., 1985. Adaptive strategies of woody species in neotropical savannas. Biology Revolution, vol. 60, no. 3, pp. 315-355. http://dx.doi. org/10.1111/j.1469-185X.1985.tb00420.x.

SAZIMA, I., 2009. Insect cornucopia: various bird types prey on the season's first giant cicadas in an urban park in southeastern
Brazil. Biota Neotropica, vol. 9, no. 1, pp. 259-262. http://dx.doi. org/10.1590/S1676-06032009000100027.

SEASTED, T.R. and CROSSLEY, D.A., 1984. The influence of arthropods on ecosystems. BioScience, vol. 34, no. 3, pp. 157161. http://dx.doi.org/10.2307/1309750.

SMALL, G.E., TORRES, P.J., SCHWEIZER, L.M., DUFF, J.H. and PRINGLE, C.M., 2013. Importance of terrestrial arthropods as subsidies in lowland neotropical rain forest stream ecosystems. Biotropica, vol. 45, no. 1, pp. 80-87. http://dx.doi. org/10.1111/j.1744-7429.2012.00896.x.

STAMPS, J.A. and GON, S.M., 1983. Sex-biased pattern variation in the prey of birds. Annual Review of Ecology and Systematics, vol. 14, no. 1, pp. 231-253. http://dx.doi.org/10.1146/annurev. es.14.110183.001311.

SUEUR, J., 2003. Indirect and direct acoustic aggression in cicadas: first observations in the Palaearctic genus Tibicina Amyot (Hemiptera : Cicadomorpha : Cicadidae). Journal of Natural History, vol. 37, no. 1, pp. 2931-2948. http://dx.doi.org/10.108 $0 / 0022293021000007534$.

WHITE, J. and STREHL, C.E., 1978. Xylem feeding by periodical cicada nymphs on tree roots. Ecological Entomology, London, vol. 3, no. 4, pp. 323-327. http://dx.doi.org/10.1111/j.1365-2311.1978. tb00933.x.

YANG, L.H., 2004. Periodical cicadas as resource pulses in North American forests. Science, vol. 306, no. 5701, pp. 1565-1567. PMid:15567865. http://dx.doi.org/10.1126/science.1103114.

YANG, L.H., 2005. Interactions between a detrital resource pulse and a detritivore community. Oecologia, vol. 147, no. 3, pp. 522-532. http://dx.doi.org// 10.1007/s00442-005-0276-0. PMid:16252119. http://dx.doi.org/10.1007/s00442-005-0276-0.

YANG, L.H., 2013. Resource pulses of dead periodical cicadas increase the growth of American bellflower rosettes under competitive and non-competitive conditions. Arthropod-Plant Interactions, vol. 7, no. 1, pp. 93-98. http:// 10.1007/s11829-012-9223-2.

YANG, L.H., BASTOW, J.L., SPENCE, K.O. and WRIGHT, A.N., 2008. What can we learn from resource pulses? Ecology, vol. 89, no. 3, pp. 621-634. PMid:18459327. http://dx.doi. org/10.1890/07-0175.1.

YOUNG, A.M., 1975. The population biology of neotropical cicadas. 1. Emergence of Procollina and Carineta in mountain forest. Biotropica, vol. 7, no. 4, pp. 248-258. http://dx.doi. org/10.2307/2989737.

YOUNG, A.M., 1980. Environmental partitioning in lowland tropical rain forest cicadas. Journal of the New York Entomological Society, vol. 88, no. 2, pp. 86-101. 